\title{
PERSEPSI PEMILIH PEMULA TERHADAP KINERJA PEYELENGGARA PEMILU PRESIDEN TAHUN 2014
}

\author{
Muhammad Solihin ${ }^{1}$, Tree Setiawan Pamungkas ${ }^{2}$, dan Jhon Roi Tua Purba ${ }^{3}$ \\ (Fakultas Ilmu Sosial dan Ilmu Politik, Universitas Riau Kepulauan, Indonesia) ${ }^{1}$ \\ (Fakultas Ilmu Sosial dan Ilmu Politik, Universitas Jember)² \\ sm10rome@gmail.com ${ }^{l}$
}

\begin{abstract}
Abstrack
The rapid population of beginner voters in Indonesia than in 2004-2009 should be a calculation in influencing election results. Perception of beginner voters on the performance of electoral institutions in a sense it is important to be discussed because of the independence and professionalism an important factor general election success.

This study uses the quantitative research survey. Data collection techniques by questionnaire. The sampling technique is done with strafied random sampling technique. The survey conducted on students at nine universities in Yogyakarta

Results from this study: First, Knowledge voters on electoral institutions. Voters who do not know Bawaslu that as many as 49.7 percent of respondents. As for the KPU as much as 65.1 percent of voters know; Second, the level of confidence in electoral institutions quite good 57.2 percent of voters believe; Third, the perception of the neutrality of electoral institutions 50.5 percent; and Fourth, the Electoral Institute of Professionalism 48.1 percent of voters declared "professional"; and Fifth, Satisfaction with the performance of the KPU was satisfied only 44.4 percent, while 40.5 percent expressed "not satisfied.

In conclusion the perception of beginner voters on the performance of electoral institutions KPU and Bawaslu overall is still relatively low and should be increased by way of socialization to voters.
\end{abstract}

Keywords: general election, performance of electoral institutions, beginner voters, voter perceptions

\begin{abstract}
Abstrak
Pesatnya populasi pemilih pemula di Indonesia dari tahun 2004-2009patut menjadi perhitungan dalam mempengaruhi hasil Pemilu. Persepsi pemilih pemula terhadap kinerja peyelenggara Pemilu di rasa penting untuk di bahas dikarenakan independensi dan profesionalitas peyelenggara merupakan faktor penting keberhasilan peyelenggaraanPemilu.

Penelitian ini menggunakan metode penelitian kuantitatif yakni survei. Teknik pengumpulan data dengan kuesioner. Teknik pengambilan sampel dilakukan dengan teknik strafied random sampling. Survei dilakukan terhadap mahasiswa di 9 perguruan tinggi di DIY.

Hasil dari penelitian ini: Pertama, Pengetahuan pemilih terhadap lembaga penyelenggara pemilihan umum.pemilih pemula yang tidak mengetahui Bawaslu yakni sebanyak 49,7 persen responden. Sedangkan untuk KPU sebanyak 65,1 persen pemilih pemula mengetahui; Kedua, Tingkat kepercayaan terhadap lembaga peyelenggara pemilihan umum cukup baik 57,2 persen pemilih pemula percaya; Ketiga, Persepsi terhadap netralitas lembaga penyelenggara pemilihan umum 50,5 persen; dan Keempat, Profesionalisme Lembaga Pemilu 48,1 persen pemilih pemula menyatakan "professional".; dan Kelima, Kepuasan terhadap kinerja KPU menyatakan puas hanya 44,4 persen sedangkan 40,5 persen lainnya menyatakan "tidak puas".

Kesimpulannya persepsi pemilih pemula terhadap kinerja peyelenggaraan pemilu yakni KPU dan Bawaslu secara keseluruhan masih tergolong rendah dan harus dilakukan peningkatan dengan cara sosialisasi terhadap pemilih pemula.
\end{abstract}

Kata Kunci: pemilihan umum, pemilih pemula, persepsi pemilih, kinerja peyelenggara pemilu 


\section{A. Pendahuluan}

Pada tahun 2014 ini Indonesia sedang gegap gempita dengan pesta demokrasi yang sedang berlangsung yaitu pemilihan DPR, DPD, dan DPRD dan pemilihan presiden untuk periode 2014-2019. Pada 9 april yang lalu kita baru saja melakukan pemilihan umum legislatif yang menghasilkan rekapitulasi final sebagai berikut:

Tabel 1.1

Perolehan Suara Sah Partai Pada Pileg 2014

\begin{tabular}{|l|l|l|l|}
\hline No & Partai Politik & Pemilih Sah & Prosentase (\%) \\
\hline 1 & $\begin{array}{l}\text { Partai Demokrasi Indonesia } \\
\text { Perjuangan }\end{array}$ & 23.681 .471 & 18,95 \\
\hline 2 & Partai Golkar & 18.432 .312 & 14,75 \\
\hline 3 & Partai Gerindra & 14.760 .371 & 11,81 \\
\hline 4 & Partai Demokrat & 12.728 .913 & 10,19 \\
\hline 5 & Partai Kebangkitan Bangsa & 11.298 .957 & 9,04 \\
\hline 6 & Partai Amanat Nasional & 9.481 .621 & 7,59 \\
\hline 7 & Partai Keadilan Sejahtera & 8.480 .204 & 6,79 \\
\hline 8 & Partai Nasdem & 8.402 .812 & 6,72 \\
\hline 9 & Partai Persatuan Pembangunan & 8.157 .488 & 6,53 \\
\hline 10 & Partai Hanura & 6.579 .498 & 5,26 \\
\hline \multicolumn{2}{|l}{} \\
\hline
\end{tabular}

Catatan: PBB dan PKPI tidak lolos ke DPR karena perolehan suara kurang dari 3,5 persen Parliament Threshold

Babak baru dari hasil rekapitulasi tersebut adalah pemilihan umum presiden dimana partai peserta pemilu secara otomatis diharuskan menjalin kerjasama atau koalisi dengan partai lainnya karena tidak adanya partai yang memperoleh 25 persen suarah sah yang merupakan ambang batas untuk pengajuan Presiden (President Threshold). Manuvermanuver politik pun diramaikan dengan pertemuan-pertemuan petinggi-petinggi partai yang mencari dukungan satu sama lain yang diawali oleh empat poros awal yaitu poros PDIP dengan calon presiden Joko Widodo, poros Gerindra dengan calon presiden Prabowo 
Subianto, poros Golkar dengan Abu Rizal Bakrie sebagai calon presiden dan Partai dan Poros Islam dengan isu mengandeng partai-partai islam. Akhir dari lobi-lobi politik tersebut akhirnya menghasilkan dua kandidat pasangan Calon Presiden dan Calon Wakil Presiden yang akan bertarung pada Pemilu Presiden 9 Juli 2014 yaitu pasangan pertama adalah Joko Widodo - Jusuf Kalla yang diusung PDIP, Nasdem, PKB, dan Hanura dan pasangan kedua adalah Prabowo Subianto - Hatta Rajasa yang diusung oleh Gerindra, PAN, PPP, PKS, Golkar, PKB. Sedangkan Partai Demokrat memilih tidak mendukung kedua belah pihak secara formal.

Dua kandidat Calon Presiden dan Calon Wakil Presiden saat ini menjadi topik hangat secara nasional dengan perang media yang secara kasat mata bisa kita lihat dilayar televisi dan media cetak yang masing-masing mendukung Capres dan Cawapres jagonya dengan menciptakan pemahaman-pemahaman yang berusahamengiring persepsi pemilih untuk mendukung salah satu pasangan. Persepsi Pemilih tentu menjadi tema yang menarik dikalah setiap individu mempunyai jago masing-masing dengan kriteria dan argumentasi yang mulai marak didiskusikan baik dari seminar-seminar besar ala kampus sampai seminar-seminar mini ala angkringan, burjo, dan warung tegal. Persepsi pemilih inilah yang menjadi pusat perhatian penelitian ini khususnya persepsi pemilih pemula yang umumnya berusia 17-30 tahun. Saat ini pada Pemilu 2014 berdasarkan data Komisi Pemilihan Umum (KPU) pemilih pemula yang berusia 17-20 tahun sebanyak 14 juta pemilih, sedangkan yang berusia 20-30 tahun sebanyak 45,6 juta pemilih. Jika digabungkan ada sekitar 59,6 juta pemilih pemula yang berusia 17-30 tahun atau setara dengan 30 persen pemilih pemula dari total 186.612.255 pemilih terdaftar. 30 persen pemilih pemula tersebut mengalahkan perolehan suara sah pada pemilu legislatif lalu yang dimenangi oleh PDIP yang hanya mendapat 18,95 
persen. Pemilih pemula jika dirunut pada pemilu 2004, jumlah pemilih pemula semakin meningkat yaitu mencapai sekitar 27 juta atau setara dengan 18 persen dari 147 juta pemilih. Pada pemilu 2009 sekitar 36 juta atau setara dengan 21 persen pemilih pemula dari 171 juta pemilih.

Peningkatan pemilih pemula yang semakin besar ini lah yang menjadi perhatian serius karena pemilih pemula merupakan bagian penting dalam menentukan siapa Presiden dan Wakil Presiden yang akan memegang tampuk kekuasaan pada pemilihan presiden dan wakil presiden 2014-2019 yang sebentar lagi kita laksanakan. Pemilih pemula bisa rentang umur 17-20 tahun adalah mereka yang masih duduk di bangku SMA dan Kuliah pada semester awal. Pada rentang ini biasanya pemilih pemula masih belum memiliki pandangan politik atau orientasi politik tertentu dan biasanya ini merupakan pengalaman pertama partisipasinya dalam pemilu. Akan tetapi ada juga yang kritis, mandiri, independen dan pro perubahan dikarenakan era informasi yang gesit membaca di media cetak maupun internet. Dari asupan informasi tadi karakteristrik itu cukup kondusif untuk membangun komunitas pemilih cerdas dalam pemilu yakni pemilih yang memiliki pertimbangan rasional dalam menentukan pilihannya. Misalnya karena integritas tokoh yang dicalonkan partai politik, track record-nya atau program kerja yang ditawarkan. Tidak sekedar melihat dari Elegtabilitas tokoh, wajah rupawan pasangan capres dan cawapres. Berangkat dari siginifikannya peran pemilih pemula inilah peneliti ingin mencari lebih dalam tentang persepsi pemilih pemula tentang independesi penyelenggara Pemilu.

Adapun pentingnya melakukan riset terhadap pemilih pemula di DIY terkait dengan kondisi pemilih pemula yang relatif terbuka terhadap informasi. Pemilih pemula dalam hal ini merupakan para pemilih pemula yang berstatus sebagai mahasiswa di DIY. Hal ini karena 
DIY yang terkenal sebagai kota pendidikan merupakan magnet bagi para pelajar dari luar DIY untuk menimba ilmudi perguruan tinggi - perguruan tinggi yang ada di DIY. Sehingga dengan demikian, pemilih pemula yang berstatus sebagai mahasiswa merupakan pemilih pemula yang dapat menggambarkan miniatur Indonesia dalam proes pemilihan Presiden dan Wakil Presiden tahun 2014.

\section{B. Metodelogi}

Penelitian ini menggunakan metode survei. Survei dilakukan terhadap mahasiswa perguruan tinggi di DIY. Adapun perguruan tinggi yang menjadi fokus dalam survei persepsi pemilih pemula yaitu perguruan tinggi yang berbentuk universitas dengan 3 universitas negeri dan 6 universitas swasta terbesar di DIY.

Adapun penentuan sampel dalam penelitian ini dilakukan menggunakan rumusan berikut:

$$
s=\frac{\lambda^{2} \cdot N \cdot P \cdot Q}{d^{2} \cdot(N-1)+\lambda^{2} \cdot N \cdot P \cdot Q}
$$

Di mana $\mathrm{N}=174.219$ dengan tingkat kesalahan $1 \%$, maka $\mathrm{s}=663$. Dengan demikian maka jumlah sampel minimal yang digunkan dalam penelitian ini yaitu sejumlah 663 responden, namun dalam survei ini menggunakan 1000 sampel agar jumlah sampel pada setiap universitas memnuhi persyaratan penetapan sampel. Adapun teknik pengambilan sampel dilakukan dengan teknik strafied random sampling. Teknik ini digunakan karena jumlah populasi pada setiap universitas memiliki tingkatan yang berbeda sehingga digunakan teknik sampling secara proporsional.

Berikut jumlah sampel pada masing-masing universitas di DIY, yaitu

Tabel 2.1

Daftar Populasi dan Sampel per Universitas 


\begin{tabular}{|r|l|r|r|r|}
\hline No & Nama Universitas & Populasi & Persentase & Sampel \\
\hline 1 & Universitas Gadjah Mada & 59.933 & 34,40 & 344 \\
\hline 2 & Universitas Negeri Yogyakarta & 27.462 & 15,76 & 158 \\
\hline & Universitas Islam Negeri Sunan & & & \\
3 & Kalijaga & 5.093 & 2,92 & 34 \\
\hline 4 & Universitas Islam Indonesia & 18.460 & 10,60 & 106 \\
\hline & Universitas Muhammadiyah & 17.873 & 10,26 & 103 \\
\hline 5 & Yogyakarta & 13.234 & 7,60 & 76 \\
\hline & Universitas Pembangunan Nasional & 12.953 & 7,43 & 74 \\
\hline 7 & veteran & 10.562 & 6,06 & 61 \\
\hline 7 & Universitas Ahmad Dahlan & 8.649 & 4,96 & 50 \\
\hline 8 & Universitas Sanata Darma & 174.219 & 100 & 1005 \\
\hline 9 & Universitas Atma Jaya Yogyakarta & &
\end{tabular}

Sumber: Peneliti 2014

Pelaksanaan survei dapat dilihat pada Tabel 2.2 berikut:

Tabel 2.2

Pelaksanaan Survei

\begin{tabular}{|l|l|l|}
\hline No & Tahap & Waktu \\
\hline 1 & Survey & 27 Mei 2014-14 Juni 2014 \\
\hline 2 & Pengumpulan data & 16-27 Juni 2014 \\
\hline 3 & $\begin{array}{l}\text { Pengolahan data dan penyajian } \\
\text { laporan }\end{array}$ & 27 Juni 2014-1 Juli 2014 \\
\hline
\end{tabular}

Sumber: Peneliti 2014 


\section{Hasil dan Pembahasan}

\section{Karakteristik Responden}

Jumlah responden dalam Persepsi Pemilih Pemulah tahun 2014 secara keseluruhan adalah 1005 responden (melebihi target awal yang hanya sebanyak 1000 responden). Responden tersebar di 3 Perguruan Tinggi Negeri dan 6 Perguruan Tinggi Swasta yang berada di Provinsi Yogyakarta, dengan rincian pada Tabel 3.1

Tabel 3.1

Sebaran Jumlah Responden

\begin{tabular}{|c|l|c|c|}
\hline No & \multicolumn{1}{|c|}{ Universitas } & $\begin{array}{c}\text { Jumlah } \\
\text { Responden }\end{array}$ & $\begin{array}{c}\text { Pesentase } \\
(\%)\end{array}$ \\
\hline 1 & Universitas Gadjah Mada (UGM) & 344 & 34,2 \\
\hline 2 & Universitas Negeri Yogyakarta (UNY) & 158 & 15,7 \\
\hline 3 & $\begin{array}{l}\text { Universitas Islam Negeri Sunan Kalijaga } \\
\text { (UIN) }\end{array}$ & 33 & 3,3 \\
\hline 4 & Universitas Islam Indonesia (UII) & 106 & 10,5 \\
\hline 5 & $\begin{array}{l}\text { Universitas Muhammadiyah Yogyakarta } \\
\text { (UMY) }\end{array}$ & 103 & 10,2 \\
\hline 6 & $\begin{array}{l}\text { Universitas Pembangunan Nasional } \\
\text { veteran (UPN) }\end{array}$ & 76 & 7,6 \\
\hline 7 & $\begin{array}{l}\text { Universitas Ahmad Dahlan (UAD) } \\
8\end{array}$ & 74 & 7,4 \\
\hline 9 & $\begin{array}{l}\text { Universitas Sanata Darma (USD) } \\
\text { (UAJY) Atma Jaya Yogyakarta }\end{array}$ & 61 & 6,1 \\
\hline & Total 50 & 5,0 \\
\hline
\end{tabular}

Sumber: Peneliti 2014

Ditinjau dari jenis kelamin, terdapat 533 responden laki-laki (53 persen) dan 472 responden perempuan (47 persen), dengan rincian pada Tabel 3.2.

Tabel 3.2

Jenis Kelamin

\begin{tabular}{|c|c|c|c|}
\hline No & $\begin{array}{c}\text { Jenis } \\
\text { Kelamin }\end{array}$ & $\begin{array}{c}\text { Jumlah } \\
\text { Responden }\end{array}$ & Persentase(\%) \\
\hline 1 & Laki - Laki & 533 & 53,0 \\
\hline 2 & Perempuan & 472 & 47,0 \\
\hline & Total & 1005 & 100,0 \\
\hline
\end{tabular}

Sumber: Peneliti 2014 
Sedangkan dari tingkatan usia, Responden terdiri dari umur 17 sampai dengan 25 tahun. 17 dengan jumlah 13 (1,3 persen), 18 tahun dengan jumlah 88 (8,8 persen), 19 tahun dengan jumlah 244 (24,3 persen), 20 tahun dengan jumlah 250 (24,9 persen), 21 tahun dengan jumlah 214 (21,3 persen) , 22 tahun dengan jumlah 132 (13,1 persen), 23 tahun dengan jumlah 34 (3,4 persen), 24 tahun dengan jumlah 26 (2,6 persen), dan 25 tahun dengan jumlah 4 (0,4 persen). Dengan rincian pada Tabel 3.3.

Tabel 3.3

Tingkatan Usia

\begin{tabular}{|c|c|c|c|}
\hline No & Umur & $\begin{array}{c}\text { Jumlah } \\
\text { Responden }\end{array}$ & $\begin{array}{c}\text { Persentase } \\
(\boldsymbol{\%})\end{array}$ \\
\hline 1 & 17 & 13 & 1,3 \\
\hline 2 & 18 & 88 & 8,8 \\
\hline 3 & 19 & 244 & 24,3 \\
\hline 4 & 20 & 250 & 24,9 \\
\hline 5 & 21 & 214 & 21,3 \\
\hline 6 & 22 & 132 & 13,1 \\
\hline 7 & 23 & 34 & 3,4 \\
\hline 8 & 24 & 26 & 2,6 \\
\hline 9 & 25 & 4 &, 4 \\
\hline & Total & 1005 & 100,0 \\
\hline
\end{tabular}

Sumber: Peneliti 2014

Ditinjau dari Provinsi Asal, Responden berasal dari 32 Provinsi di Indonesia. Responden terbanyak berasal dari Provinsi Daerah Istimewa Yogyakarta dengan jumlah 368 responden (36,6 persen), Provinsi Jawa Tengah dengan jumlah 201 responden (20 persen), Provinsi Jawa Barat dengan jumlah 60 responden (6 persen), Provinsi Jawa Timur dengan jumlah 56 responden (5,6 persen) dan sisanya tersebar pada provinsi yang lain yang bisa dilihat secara rinci pada Tabel 3.4 
Tabel 3.4

Provinsi Asal Responden

\begin{tabular}{|c|c|c|c|c|c|c|c|}
\hline No & Provinsi & $\begin{array}{c}\text { Jumlah } \\
\text { Responden }\end{array}$ & $\begin{array}{c}\text { Persentase } \\
(\%)\end{array}$ & No & Provinsi & $\begin{array}{c}\text { Jumlah } \\
\text { Responden }\end{array}$ & $\begin{array}{c}\text { Persentase } \\
(\%)\end{array}$ \\
\hline 1 & NAD & 2 & , 2 & 17 & Bali & 4 &, 4 \\
\hline 2 & SUMUT & 32 & 3,2 & 18 & NTB & 21 & 2,1 \\
\hline 3 & SUMBAR & 26 & 2,6 & 19 & NTT & 9 & ,9 \\
\hline 4 & Riau & 22 & 2,2 & 20 & KALBAR & 11 & 1,1 \\
\hline 5 & Jambi & 12 & 1,2 & 21 & KALTENG & 7 &, 7 \\
\hline 6 & SUMSEL & 21 & 2,1 & 22 & KALSEL & 7 & ,7 \\
\hline 7 & Bengkulu & 9 & ,9 & 23 & KALTIM & 20 & 2,0 \\
\hline 8 & Lampung & 27 & 2,7 & 24 & KALTARA & 6 & ,6 \\
\hline 9 & $\begin{array}{c}\text { Kep } \\
\text { BABEL }\end{array}$ & 5 & ,5 & 25 & SULUT & 3 & ,3 \\
\hline 10 & KEPRI & 18 & 1,8 & 26 & SULTENG & 4 &, 4 \\
\hline 11 & $\begin{array}{c}\text { DKI } \\
\text { Jakarta }\end{array}$ & 22 & 2,2 & 27 & SULSEL & 2 & , 2 \\
\hline 12 & JABAR & 60 & 6,0 & 28 & SULTRA & 3 & ,3 \\
\hline 13 & JATENG & 201 & 20,0 & 29 & Maluku & 2 &, 2 \\
\hline 14 & BANTEN & 14 & 1,4 & 30 & $\begin{array}{l}\text { Maluku } \\
\text { Utara }\end{array}$ & 3 & ,3 \\
\hline 15 & JATIM & 56 & 5,6 & 31 & Papua & 4 & ,4 \\
\hline 16 & DIY & 368 & 36,6 & 32 & $\begin{array}{c}\text { Papua } \\
\text { Barat }\end{array}$ & 4 & ,4 \\
\hline
\end{tabular}

Sumber: Peneliti 2014

Berikut Karakteristik responden ditampilkan diharapkan memberikan gambaran mengenai karakter yang nyata tentang responden.

\section{Persepsi Pemilih Pemula Terhadap Peyelenggara Pemilu Presiden}

Pada variabel Persepsi Terhadap Penyelenggara Pemilu Presiden pada penelitian Persepsi Pemilih Pemula pada 2014 dilihat dalam empat hal yakni: Pertama, Pengetahuan pemilih terhadap lembaga penyelenggara pemilihan umum; Kedua, Tingkat kepercayaan terhadap lembaga peyelenggara pemilihan umum; Ketiga, Persepsi terhadap Netralitas 
lembaga penyelenggara pemilihan umum; dan Keempat, Profesionalisme Lembaga Pemilu; dan Kelima, Kepuasan terhadap kinerja Komisi Pemilihan Umum.

\section{a. Pengetahuan Terhadap Lembaga Penyelenggara Pemilihan Umum}

Pada pertanyaan ini peneliti ingin mengatahui tingkat pengetahuan pemilih tentang Lembaga Penyelenggara Pemilihan Umum yang terdiri dari: Pertama, Badan Pengawas Pemilu; Kedua, Komisi Pemilihan Umum Pusat; Ketiga, Komisi Pemilihan Umum Provinsi; dan Keempat, Komisi Pemilihan Umum Kabupaten/Kota.

Tabel 3.5

Badan Pengawas Pemilu

\begin{tabular}{|c|c|c|}
\hline & $\begin{array}{c}\text { Jumlah } \\
\text { Responden }\end{array}$ & $\begin{array}{c}\text { Prosentase } \\
(\boldsymbol{\%})\end{array}$ \\
\hline Ya & 506 & 50,3 \\
\hline Tidak & 499 & 49,7 \\
\hline Total & 1005 & 100,0 \\
\hline
\end{tabular}

Sumber: Peneliti 2014

Pada Tabel 3.5 ternyata cukup banyak pemilih pemula yang tidak mengetahui Bawaslu. Hal ini terlihat dari 499 responden (49,7 persen) menyatakan "tidak" mengetahui lembaga penyelenggara yang bertidak dalam pengawasan pemilu ini.

Tabel 3.6

Komisi Pemilihan Umum Pusat

\begin{tabular}{|c|c|c|}
\hline Ya & $\begin{array}{c}\text { Jumlah } \\
\text { Responden }\end{array}$ & Prosentase (\%) \\
\hline Tidak & 654 & 65,1 \\
\hline Total & 351 & 34,9 \\
\hline
\end{tabular}

Sumber: Peneliti 2014

Sedangkan pada Tabel 3.6 tentang pengetahuan pemilih pemula terhadap KPU Pusat sedikit lebih baik yakni 654 responden (65,1 persen) menyatakan "ya" 
mengetahui KPU Pusat. Namun cukup banyak juga yang tidak mengetahui hal ini terlihat dari 351 responden (34,9 persen) menyatakan "tidak" mengetahui.

Tabel 3.7

Komisi Pemilihan Umum Provinsi

\begin{tabular}{|c|c|c|}
\hline & $\begin{array}{c}\text { Jumlah } \\
\text { Responden }\end{array}$ & $\begin{array}{c}\text { Persentase } \\
(\boldsymbol{\%})\end{array}$ \\
\hline Ya & 455 & 45,3 \\
\hline Tidak & 550 & 54,7 \\
\hline Total & 1005 & 100,0 \\
\hline
\end{tabular}

Sumber: Peneliti 2014

Pada Tabel 3.7 ternyata banyak pemilih pemula yang tidak mengetahui KPU Provinsi. Hal ini terlihat dari 550 responden (54,7 persen) menyatakan "tidak" mengetahui lembaga penyelenggara pemilu ini. Dan sisanya menyatakan mengetahui.

Tabel 3.8

Komisi Pemilihan Umum Kab/Kota

\begin{tabular}{|c|c|c|}
\hline & $\begin{array}{c}\text { Jumlah } \\
\text { Responden }\end{array}$ & $\begin{array}{c}\text { Persentase } \\
(\boldsymbol{\%})\end{array}$ \\
\hline Ya & 520 & 51,7 \\
\hline Tidak & 485 & 48,3 \\
\hline Total & 1005 & 100,0 \\
\hline
\end{tabular}

Sumber: Peneliti 2014

Sedangkan pada Tabel 3.8 tentang pengetahuan pemilih pemula terhadap KPU Kab/Kota juga cukup menghawatirkan karena hanya 520 responden (51,7 persen) menyatakan "ya" mengetahui KPU Pusat. Namun hampir separuh juga yang tidak mengetahui hal ini terlihat dari 485 responden (48,3 persen) menyatakan "tidak" mengetahui.

\section{b. Kepercayaan Terhadap Lembaga Peyelenggara Pemilihan Umum}


Pada pertanyaan ini peneliti menyinggung "Kepercayaan Pemilih Terhadap

Peyelenggara Pemilu"

Tabel 3.9

Kepercayaan

\begin{tabular}{|c|c|c|}
\hline & $\begin{array}{c}\text { Jumlah } \\
\text { Responden }\end{array}$ & $\begin{array}{c}\text { Prosentase } \\
(\boldsymbol{\%})\end{array}$ \\
\hline Sangat Percaya & 39 & 3,9 \\
\hline Percaya & 575 & 57,2 \\
\hline Ragu-ragu & 362 & 36,0 \\
\hline Tidak Percaya & 16 & 1,6 \\
\hline $\begin{array}{c}\text { Sangat Tidak } \\
\text { Percaya }\end{array}$ & 13 & 1,3 \\
\hline Total & 1005 & 100,0 \\
\hline
\end{tabular}

Sumber: Peneliti 2014

Pada tabel 3.9 terlihat sebanyak 575 responden (57,2 persen) menyatakan “percaya" terhadap lembaga pemilihan umum. Sedangkan 362 (36,0 persen) menjawab "ragu-ragu" dan sisanya menjawab "sangat percaya", "tidak percaya" dan "sangat tidak percaya"

\section{c. Netralitas lembaga penyelenggara pemilihan umum}

Pada pertanyaan ini peneliti menyinggung "Persepsi Pemilih Tentang Netralitas Peyelenggara Pemilu”

Tabel 3.10

Netralitas

\begin{tabular}{|c|c|c|}
\hline & $\begin{array}{c}\text { Jumlah } \\
\text { Responden }\end{array}$ & $\begin{array}{c}\text { Prosentase } \\
(\mathbf{\%})\end{array}$ \\
\hline Netral & 508 & 50,5 \\
\hline Tidak Netral & 136 & 13,5 \\
\hline Tidak Tahu & 361 & 35,9 \\
\hline Total & 1005 & 100,0 \\
\hline
\end{tabular}


Sumber: Peneliti 2014

Pada Tabel 3.10 terkait persepsi pemilih pemula tentang netralitas lembaga penyelenggara pemilihan umum ditemukan bahwa hanya 508 responden $(50,5$ persen $)$ yang menyatakan lembaga penyelenggara dalam posisi netral. Sedangkan 361 Responden (35,9 persen) menyatakan "ragu-ragu" dan sisanya menjawab lembaga pemilu "tidak netral.

\section{d. Profesionalisme Lembaga Pemilu}

Pada pertanyaan ini peneliti menyinggung persepsi pemilih dalam hal "Profesionalisme Peyelenggara Pemilu"

Tabel 3.11

Profesionalisme

\begin{tabular}{|c|c|c|}
\hline & $\begin{array}{c}\text { Jumlah } \\
\text { Responden }\end{array}$ & $\begin{array}{c}\text { Prosentase } \\
(\boldsymbol{\%})\end{array}$ \\
\hline Profesional & 483 & 48,1 \\
\hline Tidak Profesional & 148 & 14,7 \\
\hline Tidak tahu & 374 & 37,2 \\
\hline Total & 1005 & 100,0 \\
\hline
\end{tabular}

Sumber: Peneliti 2014

Berdasarkan hasil pada Tabel 3.11 hanya 483 responden (48,1 persen) yang menyatakan lembaga penyelenggara pemilu "profesional". Sedangkan 374 Responden (37,2 persen) menjawab "tidak tahu" dan sisanya menyatakan lembaga tersebut tidak profesional.

\section{e. Kepuasan Terhadap Kinerja KPU}

Pada pertanyaan ini peneliti menyinggung persepsi pemilih tentang "Kepuasan Pemilih Terhadap Kinerja KPU”

Tabel 3.12

Kepuasan Kinerja KPU 


\begin{tabular}{|c|c|c|}
\hline & $\begin{array}{c}\text { Jumlah } \\
\text { Responden }\end{array}$ & Prosentase (\%) \\
\hline Sangat Puas & 19 & 1,9 \\
\hline Puas & 446 & 44,4 \\
\hline Ragu-Ragu & 407 & 40,5 \\
\hline Tidak Puas & 119 & 11,8 \\
\hline $\begin{array}{c}\text { Sangat Tidak } \\
\text { Puas }\end{array}$ & 14 & 1,4 \\
\hline Total & 1005 & 100,0 \\
\hline
\end{tabular}

Sumber: Peneliti 2014

Berdasarkan Tabel 3.12 digambarkan ternyata hanya 446 responden $(44,4$ persen) yang menyatakan "Puas" terhadap kinerja KPU dan 19 responden (1,9 persen) yang menyatakan "sangat puas". Jika ditelusuri banyak responden yang "ragu-ragu" dalam menjawab yakni 407 responden (40,5 persen) dan sisanya menjawab "tidak puas" dan "sangat tidak puas"

Adapun kesimpulan pada variabel Persepsi Terhadap Penyelenggara Pemilu Presiden pada penelitian Persepsi Pemilih Pemula pada 2014 tergolong (Rendah) dilihat dalam empat hal yakni: Pertama, Pengetahuan pemilih terhadap lembaga penyelenggara pemilihan umum tergolong (Rendah) karena hanya 50 persen (Bawaslu), 65 persen (KPU Pusat), 45 persen (KPU Provinsi), dan 50 persen (KPU Kab/Kota); Kedua, Tingkat kepercayaan terhadap lembaga peyelenggara pemilihan umum tergolong (Sedang) karena 57 persen percaya dan 3 persen sangat percaya; Ketiga, Persepsi terhadap Netralitas lembaga penyelenggara pemilihan umum tergolong (Rendah) dikarenakan hanya 50 persen yang menyatakan Netral; dan Keempat, Profesionalisme Lembaga Pemilu tergolong (Rendah) dikarenakan hanya 48 persen yang menyatakan profesional; dan Kelima, Kepuasan terhadap kinerja 
Komisi Pemilihan Umum juga tergolong (Rendah) karena hanya 44 persen yang merasa puas dan 2 persen yang menyatakan Sangat Puas.

\section{Kesimpulan}

Persepsi Terhadap Penyelenggara Pemilu Presiden pada penelitian Persepsi Pemilih Pemula pada 2014 tergolong rendah dan harus lebih di tingkatkan. Hal ini harus ditindaklanjuti oleh lembaga penyelenggara pemilu seperti KPU dan Bawaslu untuk lebih giat lagi bersosialisasi. Serta memperbaiki kinerjanya karena tingkat kepercayaan yang tidak tergolong tinggi dan persepsi pemilih tentang netralitas dan profesionlalisme lembaga ini masih tergolong rendah. Hal ini dibuktikan:

- Cukup banyak pemilih pemula yang tidak mengetahui Bawaslu yakni sebanyak 49,7 persen responden. Sedangkan untuk KPU 65,1 persen pemilih pemula mengetahui.

- 57,2 persen pemilih pemula percaya terhadap lembaga peyelenggara pemilihan umum.

- 50,5 persen menyatakan lembaga penyelenggara pemilihan umum netral, namun 35,9 persen masih menyatakan ragu-ragu.

- Untuk profesionalisme lembaga pemilu 48,1 persen pemilih pemula menyatakan "professional". 
- Kepuasan Terhadap Kinerja KPU ternyata pemilih pemula menyatakan puas hanya 44,4 persen sedangkan 40,5 persen lainnya menyatakan "tidak puas"

\section{Daftar Pustaka}

Sugiyono. 2009. Memahami Penelitian Kualitatif. Bandung: Alfabeta

Creswell, John W. 2012. Research Design Pendekatan Kualitatif, Kuantitatif, dan Mixed. Yogyakarta: Pustaka Pelajar

KPU. 2014. Perolehan Suara Sah Partai Pada Pemilu legislative. Jakarta: KPU 